\title{
Gabriele Rippl Introduction: Towards a New Monumentalism?
}

Gabriele Rippl, Universität Bern

E-Mail: gabriele.rippl@ens.unibe.ch

In summer 2012 the Grimaldi Forum Monaco hosted the exhibition Extra Large. Oeuvres monumentales de la collection du Centre Pompidou à Monaco with installations and sculptures on display by Anish Kapoor, Alain Séchas, Andreas Gursky, Sol LeWitt and others. Due to the huge format and grand scale of the exhibited art works and their spatial relationship to the viewer the organizers promised a unique experience of intense emotional impact, of collective immersion and public communication. As this example demonstrates, a new contemporary monumentalism has become an important aesthetic concept over recent years for artists, art historians and exhibition curators alike. Thus, it is opportune now to explore today's discourses on monumentalism as well as current manifestations of new monumental modes in contemporary literature, and to discuss if and how they relate to the wane of postmodernism. 'Monumentalism' is commonly defined as a "construction, especially of buildings, on a grand scale", often sponsored by the state, which are intended to glorify a nation or a regime in a grandiose manner, and the adjective 'monumental' is used for something "great in importance, extent, or size", also as grandiose style. ${ }^{1}$ As Jelle Bouwhuis and Margriet Schavemaker explain in the catalogue of the exhibition Monumentalism: History, National Identity and Contemporary Art at the Stedelijk Museum in Amsterdam which they curated in 2010, newly founded nation states in the late nineteenth century demarcated and embellished their territories by means of majestic monuments, celebrating heroes and key historical events from the national past. One would expect that in the current globalized society such merging of national space and time would have ceased to exist; however, the renewed significance of history and national identity in contemporary culture and politics suggests otherwise. This insight leads Bouwhuis and Schavemaker to raise questions such as: What does this contemporary 'monu-

1 “Monumentalism". The OED Online. acc. 13 June 2013 <http://oxforddictionaries.com>. 
mentalism' signify? And is it truly a form of monumentalism or rather post- or anti-monumentalism? They use the term 'monument-alism' in a broad sense to mean

a general orientation toward the past and an examination of historically-rooted standards of national identity, such as cultural heritage, monuments, visual culture, and language. Globalization (international commerce) and trans-nationalism (the interplay of migratory movements and cultural exchange) erode those standards, and the obvious concept of national identity. Contemporary art's response is fragmentation, heterogeneity, and a critical approach toward questions of identity. $(2010,58)$

When the curators Bouwhuis and Schavemaker speak about fragmentation, heterogeneity and critical approaches to notions of identity in contemporary art, literary scholars are reminded of postmodernist literature, which has characteristically queried and ironized any homogenizing discourse and has been strongly opposed to the sense of the monumental which it distrusted and denigrated (cf. Leerssen 2010, 136). ${ }^{2}$ Although not entirely free of traits of megalomania, postmodernism was anti-monumental, at least in the understanding of its main proponents, who intensely debated art's complicity in political forms of monumentalism. Since the wane of postmodernism in the 1990s, however, monumentalism and monumental art forms and genres seem to be on the increase again. This special issue of ANGLIA would like to stimulate a debate about the concept of a new, contemporary monumentalism within the humanities. The issue's contributors negotiate this aesthetic, cultural and political category in connection with contemporary literature, theatre, film, national monuments and Anglophone culture in general and tackle a number of central questions: Has the new globalized world order indeed eroded national thought and do fragmentation, heterogeneity and the critical approach toward questions of identity which characterized artistic and literary postmodernism still hold true? Is the monumental in a post-monumental age still excessively bombastic and self-importantly bloated or has it developed self-reflexive forms of skepticism? What do the present manifestations of monumentalism have to say about contemporary Anglophone literature and culture, and is their function, as recently suggested by Jonathan Kalb, that of an antidote for "the endemic "hurry sickness' of the media era, with its compulsive multi-tasking, sixty-second sitcoms, pop-ups within pop-ups, and epidemic attention deficit disorder" (2011, 2)? According to Kalb, we have been assaulted by our massive engines of mediated distraction and "the greatest creative emergency in performing arts today seems

2 Cf. Joep Leerssen, “Size, Seriousness and the Sublime”, Bouwhuis \& Schavemaker, 116-137, here 136. 
to [be] the media's universal leveling and trivializing effects" $(2011,189)$. Looking at several very diverse epic theatre productions, Kalb states that what binds them together is that they provide the opportunity

for thinking theatergoers in the media age to resist the maddening, ubiquitous, and nearly
irresistible pressure to reduce, abbreviate, and trivialize. Ours is an era of notoriously min-
uscule attention spans, when time has generally become more valuable than money for
the social class that attends high-profile theater, yet that class needs occasional relief from
image-swarm, from the split screens, quick cuts, bullet lists, and call-waiting that keep it
caffeinated. (2011, 16)

Kalb suggests that many people today have gone back to reading lengthy novels, an activity that does "not fit the rush-rush of postmodern lifestyle" $(2011,16)$ and argues that "[s]o much around us is perforce distilled and fragmented that we long for the fullness of comprehensively conceived worlds, long to lose ourselves in elaborate and epic story arcs, savor panoramic vistas, and ponder quixotic concepts of the monumental" $(2011,16)$.

Indeed, one can detect a new tendency towards "great lengths" (to use Jonathan Kalb's term) in the realm of fiction: Novels of great length are common in contemporary British literature, especially in fantasy fiction and historical novels such as Susanna Clarke's Jonathan Strange \& Mr Norrell (2004; over 1,000 pages); Hilary Mantel's Thomas Cromwell trilogy of which Wolf Hall (2009; over 670 pages) and its sequel Bring Up the Bodies (2012; 432 pages) are the first two volumes; A. S. Byatt's The Children's Book (2009; over 670 pages); and J. K. Rowling's Harry Potter series (1997-2007; all seven volumes together almost 4,200 pages). A Suitable Boy by the Anglophone Indian writer Vikram Seth (1993; approx. 1,500 pages) and Amitav Ghosh's Ibis Trilogy, of which Sea of Poppies (2008; over 500 pages) and River of Smoke (2011; over 500 pages) are the first two published volumes, are all examples from contemporary postcolonial fiction of great length. In the U.S.A., David Foster Wallace's doorstop novel Infinite Jest (1996) is a vast epic of almost 1,100 pages; William T. Vollmann, too, is famous for works of monumental length (even if in works like The Atlas, 1996, the vignette serves as the basic unit), for instance his seven-volume portrait of America, America Rising Up and Rising Down (2003), encompasses 3,300 pages, and his novel Europe Central (2005) has more than 1,000 pages. Robert Rebein adds more titles to the list of contemporary American novels of monumental length:

Underworld (1997) is Don DeLillo's eleventh novel and a work of enormous scale and ambition, bearing immediate comparison with several other mega-novels of recent years, including David Forster Wallace's Infinite Jest, William T. Vollmann's Fathers and Crows, William H. Gass's The Tunnel, Thomas Pynchon's Mason \& Dixon, and Leslie Marmon Silko's Almanac of the Dead. To give some idea of the scale of these works: consider that 
the whole of Cormac McCarthy's Border Trilogy totals only 1,020 pages, while Infinite Jest weighs in at 1,079 pages, Fathers and Crows at nearly 1,000. In the above company, Underworld appears relatively slim at 827 pages; more important, it actually justifies its length and, of all these works, is the most accomplished formally. $(2001,173)$

Don DeLillo has commented on the monumental length of many contemporary mega-novels in an interview: "[D]on't some writers write long, challenging novels as a way of refusing to become part of the process of consumption, of rampart consumption and instant waste? There's a small undercurrent of protest there" (Ulin 1997, n.p.). Kalb's explanation of new monumental forms in today's culture presented above seconds DeLillo's statement; both underline the effort of writers and readers to criticize and escape contemporary modes of instant consumption and 'fast-food' cultural products. When we turn to comics, it is true that the comic strip with its succinct minimalist aesthetics proves to be very successful today, however, within the genre there are also works of epic length such as Neil Gaiman's 10-volume The Sandman (1988-1996), a graphic novel of over 2,000 pages. Another striking feature of contemporary literature are poems of epic scope such as Derek Walcott's Omeros (1990) (see Neumann's and Sauerberg's contributions in this volume). Not only is the epic "literature's most monumental genre and the literary kind most intimately tied to Walcott's monumental task of commemorating his Caribbean people, place, and culture" (Rotella 2004, 163), by rewriting Homer's The Odyssey, Walcott's Omeros also draws on the symbolic and cultural value of one of the most monumental literary texts of the Western canon. Last but not least, one should also mention lengthy video installations such as Christian Marclay's 24-hour video The Clock (2010) and Douglas Gordon's 24 Hour Psycho (1993). ${ }^{3}$

So far we have discussed new modes and forms of monumentalism as phenomena of great length, critical of today's culture industry. But a look at the U. S.-American debates and the fact that at the end of the twentieth century critics and writers have mapped postmodernism's wane and announced the emergence of "post-postmodernism" (David Foster Wallace, Robert L. McLaughlin) and the return of a "new realism" (Robert Rebein), ${ }^{4}$ all serve to bring into focus additional monumental aspects of contemporary culture. Stephen J. Burn has analyzed the 1990s as a transitional decade for American fiction, the "[c]losing time in the funhouse" $(2008,9)$, and diagnosed a general skepticism towards the

3 Cf. Haberer \& Frohne 2012.

4 Rebein sees in the revitalization of realism and a renewed importance of the concept of place in late twentieth-century American literature two of the most significant developments. For a discussion of the end of postmodernism and the rise of 'neo-realism', cf. also Claviez \& Moos (2004) and Toth (2012). 
playfulness and narcissism of metafiction, the return to a more "conventional plot grounded in a recognizable world" $(2008,20)$, a "synthesis between realist and self-reflexive modes" $(2008,21)$ and a more obvious preoccupation "with notions of character" $(2008,23)$. In the 1990s, critics began to detect new aesthetic features in Anglophone literary texts and tried to come up with tags and labels for what looks like a new literary and cultural period after postmodernism. It was the 1993 essay "E Unibus Pluram: Television and U.S. Fiction” by the U.S. novelist David Foster Wallace which triggered the debate on the wane of postmodernism. He detected and discussed the new mimetic, realist aesthetics (cf. 1993, 168) of "most U.S. fiction writers under forty" $(1993,167)$ whose writing in the 1990s was at odds with the cool "ironic postmodern self-consciousness" $(1993,161)$ of the first generation of postmodernist writers. Wallace not only used the term "post-postmodernism" when referring to the new U.S. fiction of the 1990s which distances itself from postmodernism's "irony [which] tyrannizes us" (1993, 183), he also spoke of "hyperrealism," and a new "fiction of image" or "image-fiction." 5 This new "imagist fiction" (Wallace 1993, 173) is a "natural adaptation of the hoary techniques of literary realism to a nineties world whose defining boundaries have been deformed by electric signal” (Wallace 1993, 172).

It has transpired that the two most influential tags for contemporary literature and its new aesthetics are "post-postmodernist" (in spite of the fact that the 'post', due to its complicity with concepts of teleological development, has been criticized ever since the 1980s) and "neo-realist". This new aesthetics is according to the claims of critics like Michael Benton et al. (2003) and Nicoline Timmer (2010) - one of trust, ethical responsibility, affect, sincerity and authenticity; it embraces a new engagement with the real, new efforts to communicate and allow for communal bonding, as well as emotional intensity and mutuality, with less interest in exclusively self-reflexive, self-referential, ironic, meta-fictional strategies.

[T] he most ambitious [American] literary fiction today, written by a generation of writers born in the sixties or seventies ... we can detect an incentive to move beyond what is perceived as a debilitating way of framing what it means to be human: the postmodern perspective on subjectivity. Most notable in the work of this younger generation of writers is the emphatic expression of feelings and sentiments, a drive towards inter-subjec-

5 According to Wallace, image-fiction demands "fictional access behind lenses and screens and headlines and re-imagining what human life might truly be like over across the chasms of illusion, mediation, demographics, marketing, image, and appearance, image-fiction is paradoxically trying to restore what's (mis)taken for 'real' to three whole dimensions, to reconstruct a univocally round world out of disparate streams of flat sights” (Wallace 1993, 173). 
tive connection and communication ... Their texts perform a complicit and complicated critique on certain aspects of postmodern subjectivity, especially on the perceived solipsistic quality of the subjective postmodern experience world, and envision possible reconfigurations of subjectivity that can no longer be framed, I believe, as 'postmodern'. (Timmer 2010, 13)

Writers like David Foster Wallace, Dave Eggers and Mark Z. Danielewski not only write mammoth novels, they also - says Timmer - "re-humanize subjectivity" (Timmer 2010, 18 and passim), and hence rebel against the aesthetics and ethics of the first generation of postmodernists, and the sarcasm, cynicism and irony which permeate the latter's works. Recent historical events such as the attack on the World Trade Center have often functioned as turning points in the intellectual debate, "marking a change in how we think of our 'selves', our identity, and in how we interpret our experience world" (Timmer 2010, 16f.) Likewise, emphatic feelings (and not merely cognition) and a "restructuring of 'affect”' (Timmer 2010, 44) become highly relevant in fiction today (after having been largely absent in cerebral postmodernist literature and art), as do "other aspects of subjectivity, most notably the interpersonal construction of a sense of self" (Timmer 2010, 22), its sociality and connectivity. The development of a new ethics (cf. Middeke 2011; Zapf 2008) and aesthetics in fiction (in which Wallace was a key figure) signals what Timmer and others have called "a post-postmodern turn in contemporary fiction" $(2010,23)$; she discerns "a potential structure of a 'we' which revolves around the possibility of sharing feelings" (2010, 46), which characterizes this fiction as relational and empathy provoking.

Needless to say, we are well advised to handle Timmer's sweeping claims with caution, but she is supported by other literary critics and art historians. Following their lead and linking it with the topic of this special issue, the new monumentalism in Anglophone literature and culture not only manifests itself in phenomena based on 'great lengths', momentous topics and monumental genres but also via a new aesthetics of collectivity, sociality and connectivity, one of 'emphatic feelings', 'affect' and 'immersion'. This replaces the cerebral character of postmodernist art and its strategies of ironic subversion of grand narratives with new offers of collective experience of intense emotional and bodily effects. Many writers and playwrights, too, now seem to make use of a new language which has turned its back on minimalistic linguistic experiments and show an interest in provoking intense feelings and emotions in the recipients by using pathos formulas which up to now have been associated with popular culture. Cases in point are for instance David Wroblewski's epic novel The Story of Edgar Sawtelle (2008) and the filmic examples Elisabeth Bronfen discusses in her essay "Monumental Cleopatra: Hollywood's Epic Film as Historical Re-Imagination". The excessive visual style of monumental Hollywood 
films such as Scott's Gladiator (2005), DeMille's Cleopatra (1934) and Mankiewicz's Cleopatra (1963) brings grand events of the ancient world to the screen, thus appropriating the past for the present in an affective, visceral historical re-imagination. However, the monumentalist style - so Bronfen's argument adapts itself to each era. The recent movie Gladiator, for instance, attests to the comeback of an epic monumentalism in that it taps into the affective charge of this genre's grand mythic re-figuration of the past. By citing the monumentalism of Mankiewicz' visual style in the context of a narrative predicated on the awe and pity elicited by tragic heroism, Gladiator leaves behind postmodernism's 'anything goes'; it foregoes the critical irony of the postmodern by again employing the strategies of affective identification.

In his essay "Marathon Theater as Anti-Monument: The Curious Case of Gatz" Jonathan Kalb discusses a conspicuous and persistent feature of the EuroAmerican cultural landscape in recent decades, that of marathon theater. While marathon play-going with its roots in ancient Athenian festival performances is nothing new, Kalb maintains that the current wave of marathon theater - what he considers as the "slow food" of theatrical art - distinguishes itself due to its defiance of "the maddening information-age imperative towards ever-increasing brevity, rush and trivialization" and works as an antidote to the deluge of electronic pictures, split-screens etc. and the distraction that comes with them. Theater performances of epic length allow the theatergoers not only extended imaginative experiences but also "the chance to savor rare feelings of public communion". While monumental Western theater conventions measured greatness via heroic achievements and unique expression, in the 1990s experimental companies such as Elevator Repair Service started to forge their art from mundane, ordinary material. The latter's Gatz (New York 2010), a much-acclaimed seven-hour stage adaptation of F. Scott Fitzgerald's 1925 novel The Great Gatsby, is, due to its length, a prime example of a new culture of monumentalism, however, it also functions deliberately as anti-monument by presenting an alternative to a monument (i.e. a fetish of the representation of power and elite points of view). Due to Gatz' thoroughgoing openness even the most passive spectators had no alternative to engaging in heuristic speculation which implicitly also critiqued the iconic status of its celebrated source novel.

Lars Ole Sauerberg's essay "Monumentalism and Contemporary Verse Novels" investigates the renaissance of a genre which is increasingly visible in contemporary narrative fiction. Sauerberg argues that contemporary verse novels are monumental in a double sense: First, seen in a chronological context, they can be understood as "a commemorative monument of literary conventions of the past, of a writing practice long since dead and gone" which has the potential of mobilizing new manners of reading; second, in a contemporary con- 
text, verse novels, by the "obstacle quality" of the unfamiliar verses (unlike the familiar reality-reflecting prose), allow for an extraordinary experience which is bound to make the reader stop and think. There is a third sense of monumentalism which, however, does not inhere in the verse format as such. It is "a preoccupation with issues and themes of a nature that makes the use of monumental [modes] a fitting description of their epic aspirations”, the verse novels' interest in history and epic-grandeur backgrounds which is reflected in themes of an often awe-inspiring momentousness. The rhythms and images of verse novels affect and engage the reader viscerally and offer an experience qualitatively different, i.e. more intense, from that of the prose narrative; the verse novels offer a complexity and a level of difficulty which leads to an enhancement of the reader's attention.

In her essay "Monumentalism and Monuments in Postcolonial Literatures: Dismembering Tradition" Birgit Neumann explores how postcolonial literatures critically negotiate monumentalism and, more specifically, contest the generic conventions of the epic (a genre considered to be the monumental genre). Challenging the ideological basis of monumental forms of remembrance, postcolonial literary works such as Derek Walcott's Omeros (1990) and Les Murray's Fredy Neptune (1998) exploit the epic's symbolic value for their own political and poetic agenda by questioning and ironizing monumentalism. The self-reflexive new monumentalism of these postcolonial epics is a key aesthetic strategy employed to foreground cultural difference and localize meaning while simultaneously establishing transcultural connections between seemingly diverse cultures, hence creating a "multi-vocal network of entangled histories".

Peter J. Schneemann's essay "Monumentalism as a Rhetoric of Impact" discusses the new monumental quality of contemporary exhibition projects and works of art - paintings, sculptures and installations - and argues that the new monumentalism appropriates "strategies of pop art, and in doing so, empties out and deconstructs the pathos of the grand gesture", thus it achieves its effect via clashes of pathos and ridicule, of 'the grand' and 'trash'. Schneemann convincingly demonstrates that large-scale works of art have always had a strong impact on the onlooker; they have the potential to create powerful effects such as shock and sublime amazement and are connected to a rhetoric of power, to strong emotional and physical reactions. Earlier monumental formats and largescale compositions confronted the onlooker; in contrast, the new, contemporary monumental works of art - be it the work of Olafur Eliasson, Carsten Höller, Ai WeiWei or Anish Kapoor - answer to the growing requirement for impact as the critical criterion for art and strive to effect complete immersion on the part of the onlooker. More recently, art history has undertaken a re-evaluation of the emotional responses encountered with contemporary art and a conceptualiza- 
tion of the new participatory mode which has become a defining feature of today's works of art: "Participation [i]s a dominating strategy of contemporary art. It becomes both the material and the legitimization of the monumental. The individual perceives him- or herself as a member of a collective experience. Together, they co-produce the experience and the impact they are offered to consume." To trigger interaction between members of the onlooking public, and hence produce a communal experience and collective communication in the crowd - that is what contemporary monumental works of art set out to achieve.

Bernd Nicolai's essay "New Monumentalism in Contemporary Architecture" gives an overview of different conceptions of monumentalism in twentieth- and twenty-first-century architecture and demonstrates in how much a new radical bigness has become one of the central features of the new globalized architecture over the last two decades. Among the prime examples of contemporary architectural monumentalism that are discussed are Rem Koolhaas and Ole Scheeren's CCTV Tower which has become the new landmark of Beijing, Burj Khalifa (former Burj Dubai), designed by Adrian Smith (SOM), which is one of the tallest skyscrapers in the world as well as examples of the new, worldwide emerging museum architecture such as the one to be encountered at the Abu Dhabi's Museum Quarter, the Saadiyat Island. He detects a remarkable shift in architectural monumentalism from "the paradigm of industrial aesthetics" of the first six decades of the twentieth century towards "a more liberated, joyful and bizarre architecture", which started in the 1970s with postmodern and super-structure conceptions and reached its climax in the work of Rem Koolhaas after 1990. The rejection of any kind of 'total design' of postmodern architecture opened "architecture further in a more social way for community necessities".

Finally, Christian Emden's essay "Land, Race, and Citizenship: The Political Spaces of Monumentalism in South Africa" discusses the nature of (old and new) national monuments in post-apartheid South Africa which even now, twenty years after the first free elections, remains a "democracy in transit”. In transitional systems such as South Africa, the intersection of real politics and monumentalism is particularly relevant and cannot simply be limited to the realms of aesthetics and theory; it highlights a fundamental ambivalence, namely the simultaneous appeal of transitional democracies to both heterogeneity and unity. What holds the themes of South Africa's monumentalism together is the spatial and territorial organization of political community, as exemplified by the iconic Taal and Voortrekker monuments as well as the more recent development of Pretoria's Freedom Park. Emden argues that a new form of monumentalism emerges which is largely "accidental and unintended" (and not officially sanctioned) and highlights the paradoxes which run through 
South Africa's society and political climate. This is for instance the case with the four cooling towers (painted in ANC colors) of Bloemfontein's power station, the gendered dimensions of the sandstone obelisk of the National Women's Monument and the spatial relationship between them. South Africa's new forms of monumentalism highlight the historical depth of political paradoxes, which "are intimately connected to the symbolic organization of space and the struggles over territory that mark the history of public law and constitutionalism in South Africa" and derive their critical force from "in-between and liminal spaces, and from spatial relationships, rather than from well-defined sites of remembrance".

The seven essays assembled here have been written by scholars from different disciplines and fields: literary scholars, cultural critics, philosophers, art historians, film critics and drama experts. While their essays might give the impression of being widely heterogeneous - each of them approaches the topic of "new monumentalism" from different angles, investigates different subjects and does so with different methods - they all help us to chart today's rich and multi-faceted literatures and cultures. And while the diversity might be disconcerting, there is at least one common denominator: All contributors sense a new interest and effort in contemporary writers and visual artists to create an intense emotional impact, to enhance public communication, to allow for collective immersive experiences and to cater to the longing and hunger of contemporary audiences "for the fullness of comprehensively conceived worlds ... to lose themselves in elaborate and epic story arcs, savor panoramic vistas and ponder quixotic concepts of the monumental" (Kalb, in this volume). Whether the concept of "new monumentalism" is, indeed, appropriate to characterize contemporary Anglophone literature and culture, and whether the recent developments sketched in this introduction may be interpreted as indicators of a new cultural era, remains to be seen and asks for further discussion, also against the backdrop of minimalist formats such as the comic strip, the short film, advertisements, literary vignettes, (short) short stories etc. which likewise prosper in contemporary culture and literature and may be considered monumentalism's counterpart. ${ }^{6}$ The essays in this special issue on Towards a New Monumentalism? are necessary steps in charting the field of the different monumental phenomena and aspects of today's Anglophone cultural (and political) life. ${ }^{7}$

\footnotetext{
6 A research group around Claudia Öhlschläger at the University of Paderborn currently investigates the "Pragmatik und Ästhetik des Kleinen: Literarische, visuelle und mediale Mikroformate des 20. und 21. Jahrhunderts".

7 I would like to thank Simon Reber for his incredible support; without his indefatigable efforts, this issue would not have reached the publishing house in time.
} 


\section{Works Cited}

Benton, Michael, Alan Clinton, Davin Heckman, Subhash Jaireth, Mary Quellette \& Matthew Wolf-Meyer. 2003. "What We Write and Why". Reconstruction 3.1: e-journal, <http://reconstruction.eserver.org/031/intro.html〉., acc. 13 June 2013.

Bouwhuis, Jelle \& Margriet Schavemaker, ed. 2010. Monumentalism: History, National Identity and Contemporary Art. Amsterdam: NAi Publishers.

Brooks, Neil \& Josh Toth, ed. 2007. The Mourning After: Attending the Wake of Postmodernism. New York: Rodopi.

Burn, Stephen J. 2008. Jonathan Franzen at the End of Postmodernism. New York: Continuum.

Claviez, Thomas \& Maria Moos, ed. 2004. Neorealism - Between Innovation and Continuation, Amerikastudien/American Studies 49.1.

Grimaldi Forum Monaco. 2012. "Extra Large. Oeuvres monumentales de la collection du Centre Pompidou à Monaco". <http://www.grimaldiforum.com/en/cultural-events-monaco/ agenda/monumental-220\#.UbSzAxyrISF>., acc. 17 June 2013.

Haberer, Lilian \& Ursula Frohne, ed. 2012. Kinematographische Räume: Installationsästhetik in Film und Kunst. München: Fink.

Kalb, Jonathan. 2011. Great Lengths: Seven Works of Marathon Theater. Ann Arbor: The U of Michigan P.

Leerssen, Joep. 2010. "Size, Seriousness and the Sublime”. Ed. Bouwhuis \& Schavemaker, 116-137.

McLaughlin, Robert L. 2004. "Post-Postmodern Discontent. Contemporary Fiction and the Social World". Symploke 12.1-2: 53-68.

Middeke, Martin, ed. 2011. Literature and/as Ethics. Special Issue of Anglia 129.1-2.

Rebein, Robert. 2001. Hicks, Tribes, and Dirty Realists: American Fiction after Postmodernism. Lexington: The UP of Kentucky.

Rotella, Guy. 2004. Castings: Monuments and Monumentality in Poems by Elizabeth Bishop, Robert Lowell, James Merrill, Derek Walcott, and Seamus Heaney. Nashville: Vanderbilt UP.

Ruhl, Carsten, ed. 2011. Mythos Monument: Urbane Strategien in Architektur und Kunst seit 1945. Bielefeld: transcript.

Smith, Matthew Wilson. 2007. The Total Work of Art: From Bayreuth to Cyberspace. New York: Routledge.

Timmer, Nicoline. 2010. Do You Feel It Too? The Post-Modern Syndrome in American Fiction at the Turn of the Millenium. New York: Rodopi.

Toth, Josh. 2012. The Passing of Postmodernism: A Spectroanalysis of the Contemporary. Albany: State U of New York P.

Ulin, David L. 1997. “Merging Myth and History”. Los Angeles Times, 8 October 1997. <http://articles.latimes.com/1997/oct/08/news/ls-40336/2〉., acc. 15 June 2013.

Wallace, David Foster. 1993. “E Unibus Pluram: Television and U.S. Fiction”. Review of Contemporary Fiction 13.2: 151-194.

Zapf, Hubert. 2008. "Literary Ecology and the Ethics of Texts". New Literary History 39.4: 847-868. 